\title{
Dynamics of large wood during a flash flood in two mountain catchments
}

\author{
A. Lucía ${ }^{1}$, F. Comiti ${ }^{1}$, M. Borga ${ }^{2}$, M. Cavalli ${ }^{3}$, and L. Marchi ${ }^{3}$ \\ ${ }^{1}$ Faculty of Science and Technology, Free University of Bozen-Bolzano, Bolzano, Italy \\ ${ }^{2}$ Department of Land and Agroforest Environments, University of Padova, Legnaro, Italy \\ ${ }^{3}$ CNR IRPI, Padova, Italy
}

Correspondence to: A. Lucía (Ana.LuciaVela@unibz.it)

Received: 30 January 2015 - Published in Nat. Hazards Earth Syst. Sci. Discuss.: 26 February 2015

Accepted: 26 June 2015 - Published: 6 August 2015

\begin{abstract}
Understanding and modelling the dynamics of large wood (LW) in rivers during flood events has spurred a great deal of research in recent years. However, few studies have documented the effect of high-magnitude flash floods on LW recruitment, transport and deposition. On 25 October 2011, the Magra river basin (north-western Italy) was hit by an intense rainstorm, with hourly rainfall rates up to $130 \mathrm{~mm} \mathrm{~h}^{-1}$ and event rain accumulations up to $540 \mathrm{~mm}$ in $8 \mathrm{~h}$. Such large rainfall intensities originated flash floods in the main river channels and in several tributaries, causing severe damages and loss of lives. Numerous bridges were partly or fully clogged by LW jams. A post-flood survey was carried out along the channels of two catchments that were severely and similarly affected by this event, the Gravegnola $\left(34.3 \mathrm{~km}^{2}\right)$ and Pogliaschina $\left(25.1 \mathrm{~km}^{2}\right)$. The analysis highlighted a very relevant channel widening in many channel reaches, which was more marked in the Gravegnola basin due to highly erodible material forming the slopes adjacent to the fluvial corridor. Large wood recruitment rates were very high, up to $1270 \mathrm{~m}^{3} \mathrm{~km}^{-1}$, and most of it (70-80\%) was eroded from the floodplains as a consequence of channelwidening processes, while the rest came from hillslopes processes. Overall, drainage area and channel slope are the most relevant controlling variables in explaining the reach-scale variability of LW recruitment, whereas LW deposition appears to be more complex, as correlation analysis did not evidence any statistically significant relationship with the tested controlling variables. Indeed, in-channel LW displacement during the flood has been mostly limited by the presence of bridges, given the relatively large width attained by channels after the event.
\end{abstract}

\section{Introduction}

Floods are the natural hazard which affect the largest number of people on a global scale (Jonkman, 2005), and within these events, flash floods are the cause of the highest mortality rates (Doocy, 2013). Flash floods are defined as sudden events with high peak discharges, produced by severe thunderstorms that are generally of limited areal extent (IAHSUNESCO-WMO, 1974). Despite their relevance, these phenomena are poorly understood, mainly because they cannot be extensively monitored (Borga et al., 2014). Therefore, it has been stated the need of a systematic post-event monitoring of flash floods in order to improve the understanding and the assessment of both hazard and vulnerability (Gaume and Borga, 2008; Borga et al., 2014). The intense precipitations originating the rapid and large increase in discharge in the channel network frequently trigger slope instabilities, such as landslides and debris flows, during the same event (Borga et al., 2014). These hillslope processes, coupled to the fluvial dynamics, supply large volumes of both sediments and large wood (LW) to the channels in forested catchments (Comiti et al., 2008).

The presence of LW in river systems has been demonstrated to have very positive effects, as it enhances the hydromorphological diversity of riverine habitats and it represents both a source and a retention means of organic matter within channels (Gregory et al., 2003; Wohl, 2013; Beckman and Wohl, 2014). On the other hand, LW can increase flood hazards to human development on floodplains by clogging narrow cross-sections. These are typically represented by undersized or pier-type bridges (Diehl, 1997; Schmocker and Hager, 2011; Gschnitzer et al., 2015). Indeed, follow- 
ing bridge clogging, backwater effects onset is often associated with bed aggradation, bank erosion and avulsion. As a result, bridge failure and/or large unexpected flooded areas are observed (Mazzorana et al., 2009; Ruiz-Villanueva et al., 2013a). However, wood can clog also natural sections forming debris dams or valley jams (Lancaster and Grant, 2006). These may determine increased water levels upstream of them, and could lead to dam-break flows in the event of large impounded water volumes and sudden breaching (Castiglioni, 1974; Comiti et al., 2008), similar to the temporary dams created by landslide deposits (Davies and Scott, 1997).

In-channel LW storage and its morphological effects have been studied since the 70s (e.g. Swanson and Lienkaemper, 1978) and they have been analysed quite extensively in recent decades (see for a summary Gurnell, 2014; Wohl, 2014). As with LW transport (i.e. incipient motion thresholds, travel distances, controlling variables), several field investigations have been carried out especially in mountain rivers (Faustini and Jones, 2003; Gurnell, 2003; Andreoli et al., 2007; Mao et al., 2008; Wohl and Goode, 2008; Iroumé et al., 2014, 2015), but none of these included LW transport associated with extreme events.

Indeed, modelling the dynamics of large wood in rivers during floods spurred a great deal of research in recent years (Benda et al., 2003; Mazzorana et al., 2009, 2011; Rigon et al., 2012; Ruiz-Villanueva et al., 2013b, 2014a, b). However, few studies have actually documented the effect of highmagnitude flash floods on LW dynamics collecting data on recruitment, transport and deposition rates, all information required in order to validate or develop new models on LW transport (Hassan et al., 2005). Fischer (2006) and Waldner et al. (2007) presented an inventory of the LW deposited after the catastrophic 2005 flood event which occurred in different Swiss catchments, following the previous work by Rickenmann (1997) in the same country. These studies reported a very large scatter in the relationship between drainage area and LW volume, and a predominance of LW recruitment from the floodplains. Comiti et al. (2008) and Marchi et al. (2009) analyzed a 2007 flash flood in a relatively small catchment of the Slovenian Alps. Although a detailed LW budget was not carried out, it was assessed that both hillslope processes and floodplain erosion were similarly responsible for LW recruitment, and highlighted how bridge clogging had been key in favouring hazardous channel avulsions. Kaczka (2009) made a dendrochronology study of LW deposited in a stream of the Polish Carpathians and found that most wood jams were formed during a few extreme events. More recently, Ruiz-Villanueva et al. (2013a) described the LW deposits during a flash flood event occurred in 1977 in central Spain, and compared them to the results obtained from a numerical LW transport model.

Indeed, several relevant scientific questions - and of great applicative importance for a correct river management - regarding LW dynamics during flash floods are still unclear, such as: (i) what are the most likely LW sources within a
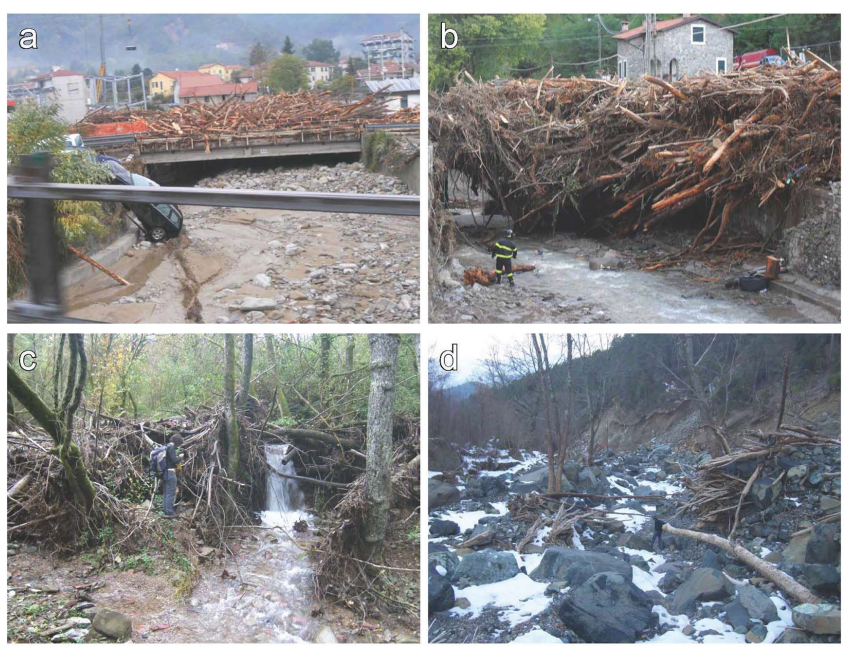

Figure 1. (a) LW clogging in the Magra river catchment after the 2011 flash flood, upstream view of a bridge in the town of Brugnato. Note also the evident sediment deposition below the bridge; (b) downstream view of a huge wood jam trapped by a bridge in the village of Pignone; source: Autorità di Bacino Interregionale del Fiume Magra and Provincia della Spezia. (c) A LW jam anchored on remaining vegetation, it retained sediment upstream; (d) LW jam deposits anchored by the remaining vegetation.

catchment? (ii) How does channel morphology affect LW dynamics (transfer vs. deposition)? (iii) What are the key variables (geomorphological and hydraulic alike) determining LW volumes transported at a given river section?

These issues were investigated in two catchments belonging to the Magra river basin (North-western Italy), where a flash flood occurred on 25 October 2011, causing major geomorphic changes in the channel network, severe economic damage, the destruction of infrastructures and the loss of nine lives (Nardi and Rinaldi, 2015). LW played an important role during this event along the basin channel network, mostly by clogging numerous bridges (Fig. 1).

\section{Study area}

The Magra river basin is located in the Tosco-Ligurian Apennines, Italy, and features a drainage area of $1717 \mathrm{~km}^{2}$, ranging from a maximum elevation of $1901 \mathrm{~m}$ a.s.l. to the sea level (Ligurian Sea). The catchment is delimitated by aligned ridges with direction NW-SE that also divide the area in two main basins with similar patterns, the main, larger $\left(1146 \mathrm{~km}^{2}\right)$ Magra basin in the east, and the Vara basin in the west $\left(571 \mathrm{~km}^{2}\right)$. The climate is temperate with a dry summer season. The mean annual precipitation in the basin is about $1700 \mathrm{~mm}$.

On 25 October 2011, rainfall intensities up to $130 \mathrm{~mm} \mathrm{~h}^{-1}$ and cumulated values up to $540 \mathrm{~mm}$ in $8 \mathrm{~h}$ were locally recorded within the Magra basin, with estimated return periods up to 300 years. In the channel network, such high- 
Table 1. Main characteristics of the studied catchments.

\begin{tabular}{lrr}
\hline Catchment & Gravegnola & Pogliaschina \\
\hline Drainage area $\left(\mathrm{km}^{2}\right)$ & 34.6 & 25.1 \\
Maximum elevation $(\mathrm{m})$ & 1205 & 721 \\
Basin relief $(\mathrm{m})$ & 1106 & 625 \\
Avg. basin slope $(\%)$ & 39 & 56 \\
Drainage density $\left(\mathrm{km} \mathrm{km}^{-2}\right)$ & 5.15 & 6.31 \\
Studied stream length $(\mathrm{km})$ & 11.2 & 19.3 \\
Number of studied river reaches & 21 & 34 \\
Avg. length of studied reaches (m) & 534 (range 116-2046) & 568 (range 44-2332) \\
Avg. channel slope of studied reaches (\%) & 5.6 & 2.6 \\
\hline
\end{tabular}

intensity precipitation led to unit peak discharges higher than $20 \mathrm{~m}^{3} \mathrm{~s}^{-1} \mathrm{~km}^{-2}$ in some tributaries of $10-20 \mathrm{~km}^{2}$ drainage area. More information on Magra catchment characteristics and on the 2011 event can be found in the work by Nardi and Rinaldi (2015) where the morphological effects of this event on the Magra river channel are analysed in detail.

LW dynamics during the October 2011 event were studied in two tributary catchments of the Vara River, i.e. the Gravegnola (drainage area $34.1 \mathrm{~km}^{2}$ ) and the Pogliaschina $\left(25.1 \mathrm{~km}^{2}\right.$ ) (Fig. 2). These two catchments were selected because they were similarly affected by the event, featuring basin-average cumulated precipitation of $350 \mathrm{~mm}$ and $380 \mathrm{~mm}$ for Pogliaschina and Gravegnola, respectively, and max unit peak discharges in the range of $15-20 \mathrm{~m}^{3} \mathrm{~s}^{-1} \mathrm{~km}^{-2}$ (Rinaldi et al., 2015). On the other hand, they differ considerably, geologically and geomorphologically. The Pogliaschina is mostly underlain by two types of sandstones (Macigno and Monte Gottero formations), whereas the Gravegnola features a higher lithological diversity, including sandstones, claystones, flysch deposits and metamorphic rocks such as ophiolites. Its tectonic structure is also more complex, and the relevance of inactive landslides deposits is more significant ( $21.1 \%$ of the area vs. $2.8 \%$ in the Pogliaschina).

The Pogliaschina catchment is more forested than the Gravegnola (92\% vs. $71 \%$ of basin area, respectively). In the Pogliaschina basin, hardwood forests (mostly composed of chestnut, Castanea sativa) cover approximately $50 \%$ of catchment, $21 \%$ is occupied by mixed forests ( $4 \%$ representing recently established stands grown on abandoned agricultural areas), and $21 \%$ by coniferous forests (maritime pine, Pinus pinaster). Around $39 \%$ of the Gravegnola basin area is covered by hardwood forests, whereas coniferous forest and mixed woodlands occupy the same percentage (approximately $16 \%$ ) of basin area. Agricultural areas (meadows, olive trees and vineyards) occupy the remaining parts of the two catchments. In both of them, urban areas are small and mostly located at low elevations.

The main characteristics of the two catchments are summarized in Table 1. The confluences of the two main channels with the Vara River lie almost at the same location (at

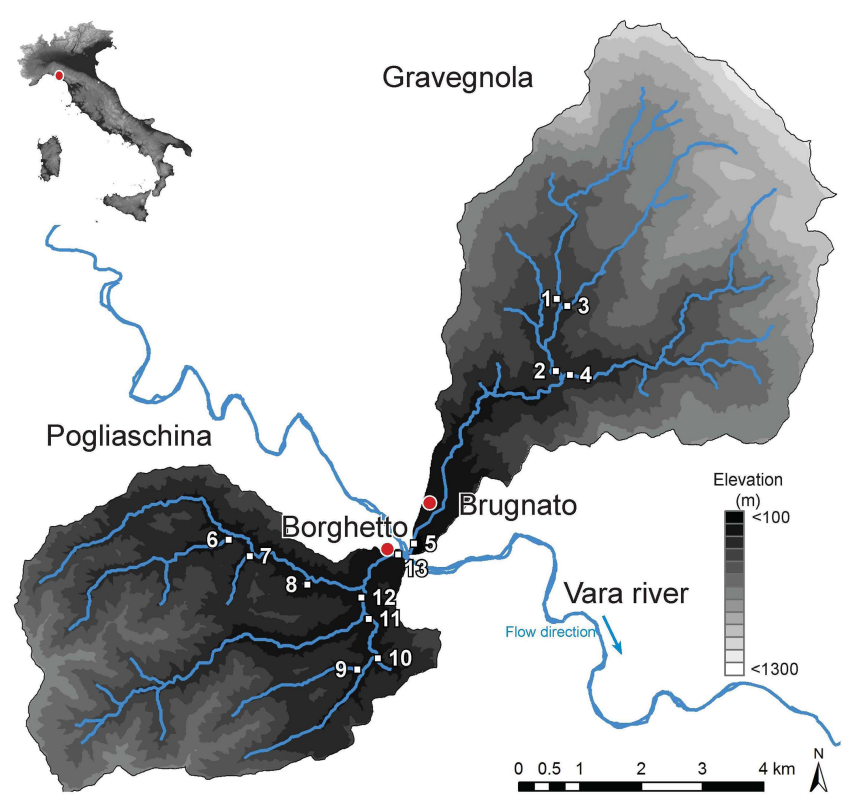

Figure 2. Geographical location and Digital Elevation Model (DEM) of the Pogliaschina and Gravegnola basin. The studied channels have been indicated with a number at their outlets: 1 . Casserola 1, 2. Casserola 2, 3. Suvero, 4. Veppo, 5. Gravegnola, 6. Pogliasca, 7. Redovego, 8. Sottano, 9. Ginepro, 10. Benoia, 11. Redarena, 12. Cassana, 13. Pogliaschina.

$\sim 94$ ma.s.1, see Fig. 2). Figure 2 shows the channels surveyed for LW analysis in the two basins.

\section{Methods}

Both GIS analysis and field surveys were carried out to investigate flood magnitude and LW dynamics in the study basins.

Peak discharges were estimated using the post-flood surveys carried out in February and November 2012, following the methodology described in Gaume and Borga (2008), which includes the topographic survey of cross-sections and energy slope and the application of the Manning-Strickler equation under the assumption of uniform flow. Two and six 
cross sections were surveyed in the Gravegnola and in the Pogliaschina channel networks, respectively. The estimated peak discharges were validated through the application of a rainfall-runoff model (Borga et al., 2007; Gaume and Borga, 2008).

\subsection{Field surveys}

Field surveys aimed to assess morphological variations and LW-related processes were carried out in November 2011, February 2012 and November 2012. The channels were subdivided into reaches, 21 in the Gravegnola and 34 in the Pogliaschina, as homogenous as possible in terms of width, channel slope and LW abundance. Reach limits were mapped using a GPS. The total surveyed channel length was $11.2 \mathrm{~km}$ in the Gravegnola and $19.3 \mathrm{~km}$ in the Pogliaschina. Reach length is on average 534 and $568 \mathrm{~m}$ in the Gravegnola and Pogliaschina catchment, respectively (Table 1). In each reach, evidences of bed incision or aggradation were noted, and, when possible, their magnitude (i.e. the vertical elevation change) was estimated.

The lateral inputs of sediment and large wood, such as landslides or debris floods, were also mapped. Moreover, it was noted whether LW from these processes actually reached the channel, as the hillslope-channel LW coupling is quite difficult to be determined from aerial photos. In the reaches featuring LW jams, their average height was measured in the field for the subsequent computation of LW jam volume through the jam areas determined from aerial photos, as will be described later in the text. Where LW deposits could not be detected from the aerial photos (i.e., covered by the canopy of remaining trees or for the shadows as in most of the Pogliaschina channel network) their size was assessed in the field by measuring the different dimensions of a geometric form (generally with a parallelepiped form) that enclosed the LW jam (Thévenet et al., 1998).

\subsection{GIS analysis}

The field surveys were integrated by a GIS analysis on the comparison of pre- and post-flood orthophotos (Fig. 3). The post-event photos were taken ad hoc in the study area by the Liguria Region on 28 October 2011 ( $0.1 \mathrm{~m}$ resolution) and 28 November 2011, taken by the Civil Protection of Friuli Venezia Giulia $(0.15 \mathrm{~m}$ resolution). The pre-event orthophotos which were used this work date to 2006 ( $0.5 \mathrm{~m}$ pixel resolution, contracted by the Italian Ministry for the Environment). Despite 5 years having passed before the flood event occurred, these orthophotos were verified to be representative of the pre-flood situation thanks to the images taken in July 2011 available in Google Earth. Indeed, the latter are the last aerial images before the event, but their resolution is coarser than for the 2006 orthophotos. The pre- and post-event channel banks were digitized, and channel width was calculated dividing channel area by its length (measured along the centreline) using a GIS. In some reaches the preevent channel was not well visible from the aerial photos due to the thick and continuous forest cover associated to narrow width. In these cases, it was assessed based on field observations. Channel widening for each reach was then calculated as the ratio between the post-event width and the pre-event width.

The areas affected by landslides as well as by lateral debris flows that delivered LW to the channel were also digitized on the post-event orthophotos. The portions of hillslopes and channels without forest vegetation in the 2006 photos were also delineated, in order to obtain by subtraction the forestcovered areas which were eroded on the hillslopes and in the floodplains during the 2011 event. The forest stand volumes present in these areas before the event were assigned based on the land use maps available for the study area and on the information provided by the National Forest Service. On the floodplains, mostly composed of mature alder woodland, an average value of $200 \mathrm{~m}^{3} \mathrm{ha}^{-1}$ was used, whereas on the hillslopes, pine $\left(150 \mathrm{~m}^{3} \mathrm{ha}^{-1}\right)$ and chestnut $\left(250 \mathrm{~m}^{3} \mathrm{ha}^{-1}\right)$ forests were distinguished. In the case the vegetation was classified as mixed forest, a value of $200 \mathrm{~m}^{3} \mathrm{ha}^{-1}$ was applied. LW recruitment (i.e. wood eroded and connected to the channel) for each reach was calculated as the surface where forest resulted to have been eroded - by hillslope and fluvial processes - multiplied by the relative stand volumes.

LW elements and jams were identified and digitized using the post-event orthophotos in the Gravegnola Creek only. The wood volume of each jam was calculated geometrically through its area and height (measured in the field), considering a 80-90\% range in porosity. The lower value in this range was observed in LW jams in Chilean creeks (Andreoli et al., 2007), whereas the higher one in French piedmont rivers (Thévenet et al., 1998). In case of single LW elements visible in the orthophotos, each of them was digitized as a line, and log length was associated to the horizontally projected line length. Each log was also assigned a class relative to its mid-length diameter, i.e. class 1 corresponds to $<20$, class 2 to $20-40$, and class 3 to $>40 \mathrm{~cm}$. Log volume were calculated as if they were solid cylinders (Cordova et al., 2007) using as diameters 10,30 and $50 \mathrm{~cm}$ for class 1,2 and 3 , respectively. In the Pogliaschina basin, due to the shadows covering most of channel bed in the orthophotos, deposited LW volume could only be derived from field measurements. In addition to LW storage measured in the field and mapped from the orthophotos, information on LW volumes cleaned out of the channels - mostly obstructions at the bridges - acquired by the Province of La Spezia in the hours after the flood, were also used in the analysis. Such transported LW portion would have not been measurable in the orthophotos, taken 3 days after the event. 

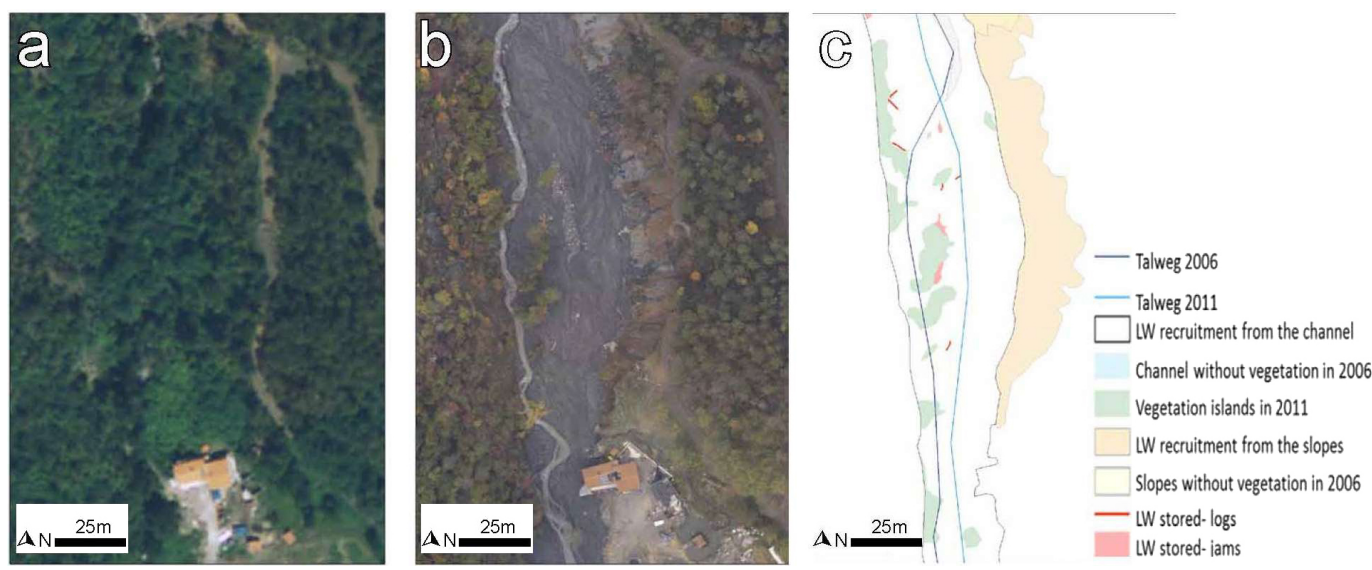

Figure 3. A reach in the Casserola 1 channel (Gravegnola) before (a) and after (b) the October 2011 event and the GIS mapping (c).

\subsection{Control factors}

Several morphological and hydraulic parameters were calculated at the reach scale in order to investigate their possible role to explain the variability in LW dynamics (i.e. recruitment, deposition, export) observed at both reach and basin scale. These parameters are the average channel slope $(S)$, the drainage area $(A)$ at the upper limit of the reach, the stream power $(\Omega)$, and the stream power index (SPI). The DEM available for the catchments ( $10 \mathrm{~m}$ resolution) was used to obtain morphological parameters such as drainage area and channel slopes. Stream power was calculated as $\Omega=\rho g Q S, \rho$ being the fluid density $\left(\mathrm{kg} \mathrm{m}^{-3}\right), g$ is the acceleration due to gravity $\left(\mathrm{m} \mathrm{s}^{-2}\right), Q$ is the peak discharge $\left(\mathrm{m}^{3} \mathrm{~s}^{-1}\right)$, and $S$ the channel slope. The stream power index (Marchi and Dalla Fontana, 2005) was calculated as the product of the channel slope and the square root of the drainage area (SPI $=S \times A^{0.5}$ ). The channel slope used in these calculations was the one extracted from the DEM. Although the flood could have caused some local variations of channel slope, these changes are small at the channel reach scale, which is the scale adopted in this study. The use of SPI is proposed because it provides a surrogate of stream power that can be applied also in catchments where, different from this study, no data on peak discharge are available.

\subsection{Data analysis}

A statistical comparison between the two catchments was carried out in order to understand the possible controlling factors determining the differences in LW dynamics at the reach scale.

The application of the Shapiro-Wilk test indicated that none of the variables presented a normal distribution, and thus a non-parametric approach was required. In order to assess whether the two study basins differ with respect to these variables, their medians were compared through the MannWhitney-Wilcoxon $U$ test. $P$ values $<0.05$ were chosen to identify statistically significant differences between the two catchments.

In order to investigate the potential factors controlling LW dynamics (recruitment, deposition and net export) at the reach scale, a correlation analysis was carried out. Because the variables do not present a normal distribution, the non-parametric Spearman correlation was adopted and calculated.

The distribution of jam areas does not follow a normal distribution, but in this case their logarithms do, thus permitting the use of ANOVA to the log-transformed variable to determine differences in the Gravegnola reaches. The Multiple Range Test using Fisher's least significant difference (LSD) procedure was used for this analysis.

The Shapiro-Wilk test was carried out on the distributions of the $\log$ length in the different channels, indicating that they do not follow a normal distribution, and neither do their logarithms. Therefore, the non-parametric Kruskal-Wallis test was adopted to determine whether significant $(p<0.05)$ differences among the channels of the Gravegnola basin exist.

\section{Results}

\subsection{Flood magnitude and frequency}

Flood magnitude resulted to be very high in both catchments (Fig. 4). In the Gravegnola basin, unit peak discharges of 17.7 and $15.9 \mathrm{~m}^{3} \mathrm{~s}^{-1} \mathrm{~km}^{-2}$ were estimated in the Veppo Creek $\left(11.8 \mathrm{~km}^{2}\right)$ and in the main Gravegnola channel $\left(30.2 \mathrm{~km}^{2}\right)$. In the Pogliaschina catchment, unit peak discharges appear to be quite variable among the different sub-basins due to large differences in rainfall inputs. In the Redarena Creek a value of $21.2 \mathrm{~m}^{3} \mathrm{~s}^{-1} \mathrm{~km}^{-2}$ (at $1.7 \mathrm{~km}^{2}$ ) was estimated, exceeded only in the Cassana catchment with $28.2 \mathrm{~m}^{3} \mathrm{~s}^{-1} \mathrm{~km}^{-2}$ (at $5.7 \mathrm{~km}^{2}$ ). The lower unit peak discharges were $17.2 \mathrm{~m}^{3} \mathrm{~s}^{-1} \mathrm{~km}^{-2}$ and $8.7 \mathrm{~m}^{3} \mathrm{~s}^{-1} \mathrm{~km}^{-2}$, in the Pogliasca $\left(3.8 \mathrm{~km}^{2}\right)$ and Pogliaschina $\left(3.4 \mathrm{~km}^{2}\right)$ creeks, 
Table 2. Summary of the channel and LW-related variables analysed statistically at the reach scale.

\begin{tabular}{|c|c|c|c|c|c|c|c|c|c|c|c|c|}
\hline & & \multicolumn{5}{|c|}{ Channel variables } & \multicolumn{5}{|c|}{ LW-related variables } & \multirow[b]{2}{*}{$\mathrm{LW}_{\text {ex R }}$} \\
\hline & & $S$ & $\begin{array}{r}A \\
\mathrm{~km}^{2}\end{array}$ & $\begin{array}{r}\Omega \\
\mathrm{Wm}^{-1}\end{array}$ & SPI & $W_{\mathrm{R}}$ & $\begin{array}{r}\mathrm{LW}_{\mathrm{r} F} \\
\mathrm{~m}^{3} \mathrm{~km}^{-1}\end{array}$ & $\begin{array}{r}\mathrm{LW}_{\mathrm{r} S} \\
\mathrm{~m}^{3} \mathrm{~km}^{-1}\end{array}$ & $\begin{array}{r}\mathrm{LW}_{\mathrm{r} T} \\
\mathrm{~m}^{3} \mathrm{~km}^{-1}\end{array}$ & $\begin{array}{r}\mathrm{LW}_{\mathrm{d}} \\
\mathrm{m}^{3} \mathrm{~km}^{-1}\end{array}$ & $\begin{array}{r}\mathrm{LW}_{\mathrm{ex}} \\
\mathrm{m}^{3}\end{array}$ & \\
\hline \multirow[t]{7}{*}{ Gravegnola } & $M_{\mathrm{e}}$ & 0.06 & 7.60 & 91273 & 104 & 8 & 555 & 131 & 706 & 393 & 481 & 0.73 \\
\hline & $\sigma$ & 0.07 & 8.71 & 40367 & 1 & 5 & 265 & 223 & 298 & 725 & 661 & 0.19 \\
\hline & $c_{\mathrm{V}}$ & 0.54 & 0.60 & 0.45 & 0.39 & 0.88 & 0.30 & 0.84 & 0.82 & 0.44 & 0.80 & 0.57 \\
\hline & Min & 0.01 & 3.14 & 30367 & 433 & 3 & 207 & 0 & 404 & 0 & 114 & 0.27 \\
\hline & $\operatorname{Max}$ & 0.28 & 30.12 & 220621 & 382 & 24 & 1143 & 971 & 1273 & 2327 & 2388 & 1.00 \\
\hline & 25 th perc. & 0.03 & 3.71 & 69393 & 130 & 5.9 & 390 & 37 & 555 & 200 & 358 & 0.67 \\
\hline & 75th perc. & 0.13 & 11.70 & 195497 & 273 & 10.5 & 691 & 266 & 982 & 636 & 966 & 0.84 \\
\hline \multirow[t]{7}{*}{ Pogliaschina } & $M_{\mathrm{e}}$ & 0.04 & 4.64 & 39255 & 57.2 & 2.85 & 140 & 0 & 180 & 8.5 & 123 & 0.48 \\
\hline & $\sigma$ & 0.03 & 5.04 & 53664 & 47 & 2 & 129 & 129 & 171 & 259 & 287 & 0.37 \\
\hline & $c_{\mathrm{V}}$ & 0.55 & 0.93 & 0.77 & 0.72 & 0.40 & 0.40 & 0.74 & 1.08 & 1.37 & 1.89 & 0.71 \\
\hline & Min. & 0.00 & 0.11 & 600 & 9 & 1 & 20 & 0 & 20 & 0 & 0 & 0.00 \\
\hline & Max. & 0.15 & 20.56 & 254800 & 262 & 8 & 520 & 486 & 626 & 1224 & 1162 & 1.00 \\
\hline & 25 th perc. & 0.02 & 1.30 & 7681 & 41.1 & 1.9 & 60 & 0 & 100 & 0 & 16 & 0.18 \\
\hline & 75th perc. & 0.05 & 6.19 & 5800 & 76.9 & 4.0 & 220 & 88 & 370 & 88 & 364 & 0.97 \\
\hline$P$ value & $<0.05$ & $<0.001$ & $<0.001$ & $<0.001$ & $<0.001$ & $<0.001$ & $<0.001$ & $<0.001$ & $<0.001$ & $<0.001$ & $>0.1$ & \\
\hline
\end{tabular}

$M_{\mathrm{e}}=$ Median

$S=$ Longitudinal channel slope

$\sigma=$ Standard deviation

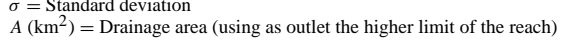

$c_{\mathrm{V}}=$ Coefficient of variation

$c_{\mathrm{V}}=$ Coefficient of variation
$\Omega\left(\mathrm{W} \mathrm{m}^{-1}\right)=$ Stream power

$\Omega\left(\mathrm{W} \mathrm{m}^{-1}\right)=\mathrm{St}$
$\mathrm{Min}=$ Minimum

Min $=$ Minimum
SPI $(\mathrm{m})=$ Stream Power Index $\left(S \times A^{0.5}\right)$

Max $=$ Maximum

$W_{\mathrm{R}}=$ Widening ratio (pre event width/ post event width)

25 th perc $=25$ th percentile

$\mathrm{LW}_{\mathrm{r} F}\left(\mathrm{~m}^{3} \mathrm{~km}^{-1}\right)=\mathrm{LW}$ recruitment rate in the fluvial corridor

75 th perc $=75$ th percentile

$\mathrm{LW}_{\mathrm{r} S}\left(\mathrm{~m}^{3} \mathrm{~km}^{-1}\right)=\mathrm{LW}$ recruitment rate in the hillslopes

$\mathrm{LW}_{\mathrm{r} T}\left(\mathrm{~m}^{3} \mathrm{~km}^{-1}\right)=\mathrm{LW}$ recruitment rate in both, fluvial corridor and hillslopes

$\mathrm{LW}_{\mathrm{d}}\left(\mathrm{m}^{3} \mathrm{~km}^{-1}\right)=\mathrm{LW}$ deposition rate

$\mathrm{LW}_{\mathrm{ex}}\left(\mathrm{m}^{3}\right)=\mathrm{LW}$ exported (LW input from upstream $+\mathrm{LW}$ recruited in the reach $-\mathrm{LW}$ deposited in the reach)

$\mathrm{LW}_{\mathrm{exR}}\left(\mathrm{m}^{3}\right)=\mathrm{LW}$ export ratio (LW Export/LW input from upstream $+\mathrm{LW}$ recruited in the reach)

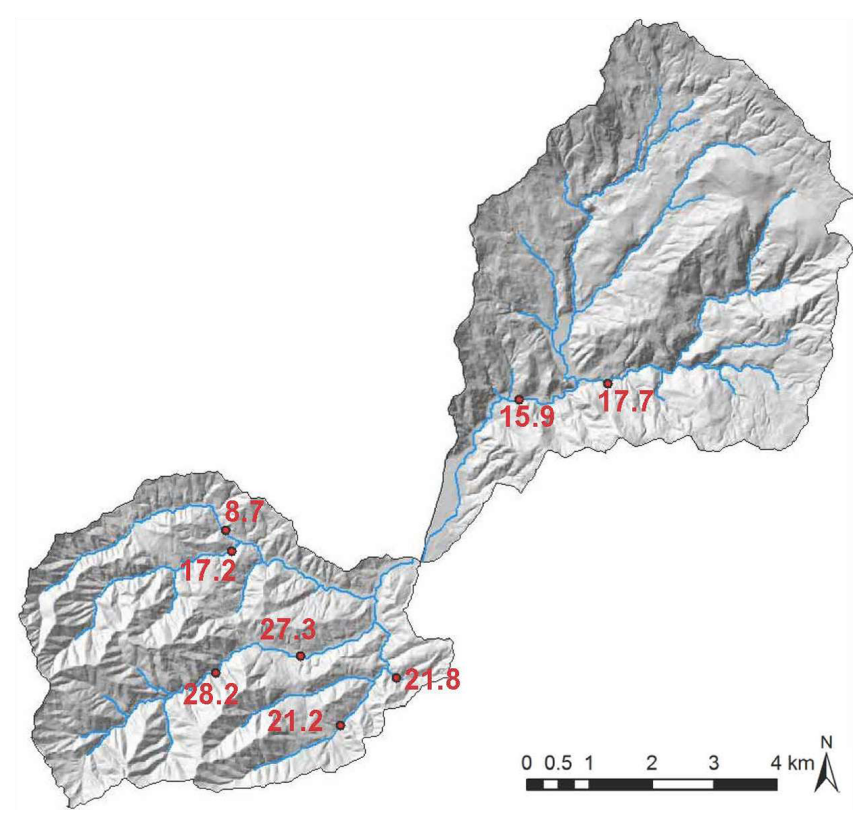

Figure 4. Location of the sections where peak discharges were measured with a red point and the value of peak discharge, in $\mathrm{m}^{3} \mathrm{~s}^{-1} \mathrm{~km}^{-2}$, are indicated in the labels. The surveyed sections are located in the following channels Veppo, Gravegnola, Pogliasca, Benoia, Redarena, Cassana, and Pogliaschina. respectively. The large variability in peak flows observed within the Pogliaschina catchment determines strong differences in the estimated flood return period, from $<30 \mathrm{yr}$ in the upper Pogliaschina Creek to about $100 \mathrm{yr}$ in the Pogliasca and $>200-500 \mathrm{yr}$ in the Cassana channels. The return period has been estimated by comparing the peak discharges reconstructed through post-flood surveys with the application of regional equations relating peak discharge - corresponding to various return periods - to drainage area.

The same peak discharge was attributed to the entire channel length represented by measured cross-section. In channels where cross-sections were not surveyed (i.e. Ginepro, Redovego and Sottano), we applied the average of the unit peak discharge measured in the Redarena, Cassana and Pogliasca to calculate their peak discharges.

\subsection{Comparison between the two study basins}

The two study catchments - apart from few channel reaches featured similarly high unit peak discharges, and have similar drainage areas and hillslope and channel gradients. However, their response to the event has been quite different in terms of morphological changes and LW dynamics.

The two catchments present significant differences (Table 2) in terms of channel slope, drainage area, stream power and stream power index, with the Gravegnola featuring higher values for all these variables. Regarding the 


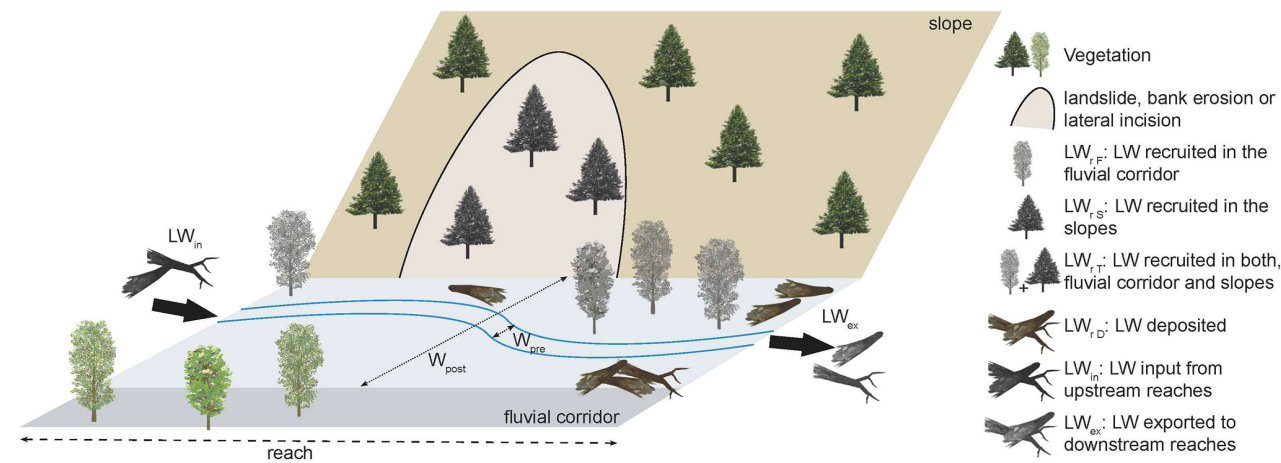

Figure 5. Conceptual model of the LW and morphological dynamics in a studied reach.

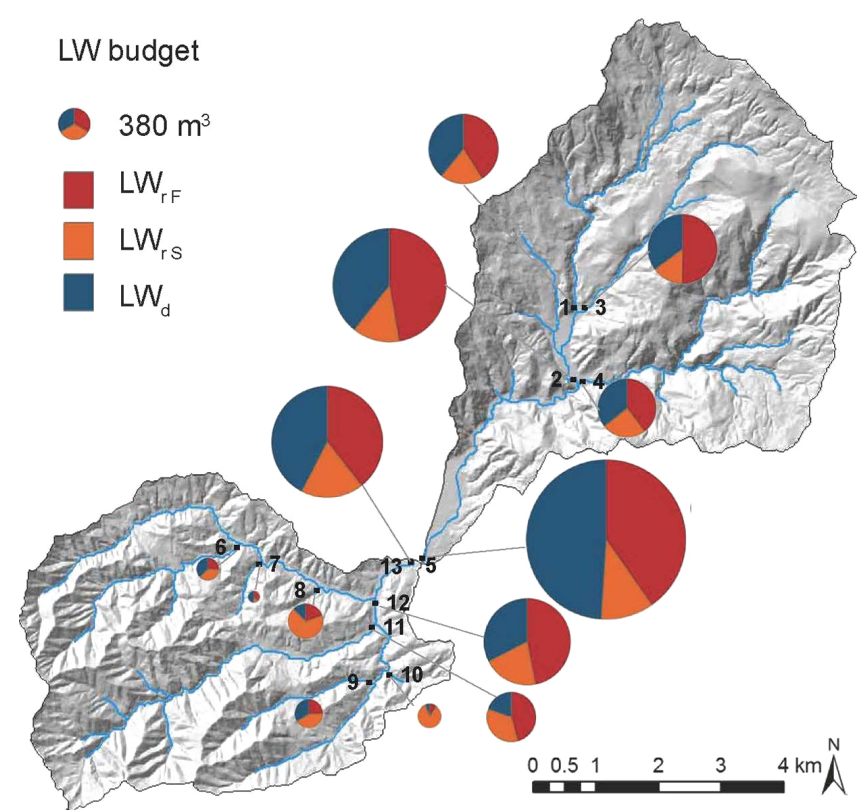

Figure 6. LW budget summarized at the sub basin scale $\left(\mathrm{LW}_{\mathrm{r} F}=\mathrm{LW}\right.$ recruitment from floodplain, $\mathrm{LW}_{\mathrm{r} S}=$ recruitment from hillslopes, $\mathrm{LW}_{\mathrm{d}}=\mathrm{LW}$ deposited) in the different subcatchments of the Gravegnola and Pogliaschina basins. The size of the circles depends on LW recruited in each sub-catchment (i.e. the input of the budget). 1 Casserola, 2 Casserola, 3 Suvero, 4 Veppo, 5 main Gravegnola, 6 Pogliasca, 7 Redovego, 8 Sottano, 9 Ginepro, 10 Benoia, 11 Redarena, 12 Cassana, 13 main Pogliaschina.

channel changes that occurred during the event, the widening ratio in the channel reaches surveyed for LW analysis results statistically significantly larger in the Gravegnola Creek (median of $\mathrm{W}_{R}$ was approximately 8 in the Gravegnola and 2.9 in the Pogliaschina). It should be noted that different widening ratios may result if different criteria for subdividing the channel network are used. Indeed, smaller differences in the widening ratios between Gravegnola and Pogliaschina arise (Rinaldi et al., 2015; Surian et al., 2015) when channel reaches of uniform length - instead of variable and linked to LW dynamics as used here - are analysed.

As with the variables describing LW dynamics during the event, they turn out significantly larger in the Gravegnola basin (Table 2), with the exception of the LW export ratio $\left(\mathrm{LW}_{\mathrm{ex} R}\right)$, which does not present significant differences. As already observed above at the basin scale, LW volume recruited in the fluvial corridor per unit of channel length $\left(\mathrm{LW}_{\mathrm{r} F}\right)$ is higher than $\mathrm{LW}$ originated from the hillslopes $\left(\mathrm{LW}_{\mathrm{r} S}\right)$ in both basins.

\subsection{LW budget}

The LW budget has been calculated for each reach as it is expressed in the Fig. 5. The LW budget during the October 2011 event for the analysed sub-catchments of Gravegnola and Pogliaschina basins (i.e. cumulating LW recruitment from hillslopes and fluvial corridor and deposition) is illustrated graphically in Fig. 6. During the event, large quantities of LW were mobilized from both river corridors and hillslopes. The amount of LW recruited in the whole Gravegnola basin results to be about $9400 \mathrm{~m}^{3}$, twice as much as the Pogliaschina $\left(4800 \mathrm{~m}^{3}\right)$. In both basins, most of the recruited LW stemmed from floodplain erosion (79\% in the Gravegnola and $68 \%$ in the Pogliaschina), with a lesser but still relevant proportion from hillslope processes, predominantly landslides. However, Fig. 6 shows that in some small sub-basins, LW recruitment from the hillslopes (landslides) has been dominant. Out of the total LW volume recruited, 96 and $74 \%$ remained stored in the channels of the Gravegnola and Pogliaschina, respectively, trapped by natural obstacles (i.e. standing vegetation) but mostly clogged at bridges.

Volumes per unit of channel area of LW deposited during the flood, taking into account the entire channel width active during the flood, result to be on average $126 \mathrm{~m}^{3} \mathrm{ha}^{-1}$, ranging from 0 to $361 \mathrm{~m}^{3} \mathrm{ha}^{-1}$ in the different reaches of the Gravegnola basin and $98 \mathrm{~m}^{3} \mathrm{ha}^{-1}$ (from 0 to $1203 \mathrm{~m}^{3} \mathrm{ha}^{-1}$ ) in the Pogliaschina catchment. Overall, only 360 and $1270 \mathrm{~m}^{3}$ were exported to the Vara River, respectively. It is evident from Fig. 6 how LW recruitment and deposition are more balanced 

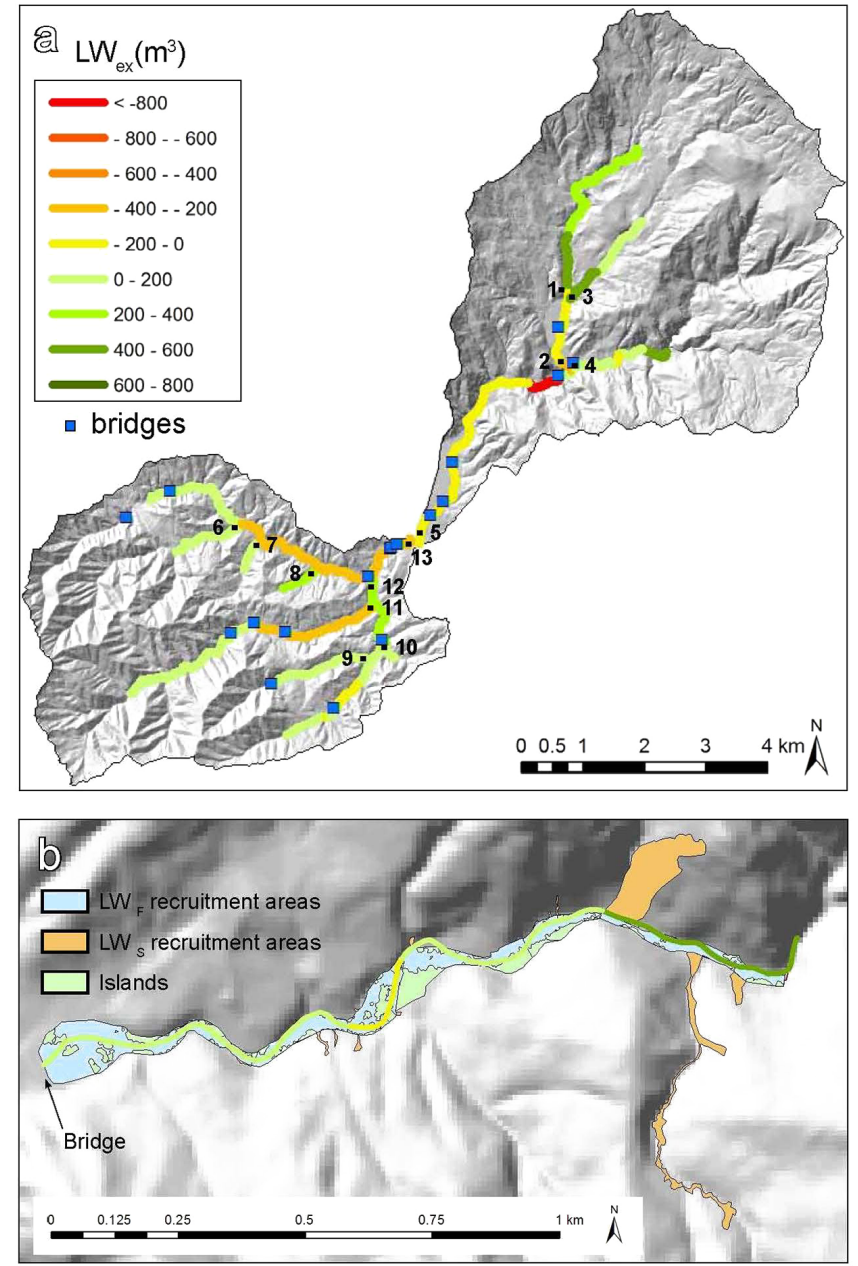

Figure 7. (a) LW exported from each reach. Numbers identify the catchments: 1 Casserola, 2 Casserola, 3 Suvero, 4 Veppo, 5 main Gravegnola, 6 Pogliasca, 7 Redovego, 8 Sottano, 9 Ginepro, 10 Benoia, 11 Redarena, 12 Cassana, 13 main Pogliaschina. (b) Detail of the Veppo Creek with the LW exported (same symbol and legend of a) and the map of the areas where LW has been recruited, as well as the remaining vegetation islands.

approaching the outlet of the two main catchments, whereas recruitment tended to exceed deposition in the smaller upstream sub-catchments.

The characteristics of LW budget varies not only among sub-catchments, as shown in Fig. 6, but also within them, at the reach scale. In order to identify the response of the different reaches in terms of LW recruitment and deposition, the analysis of non-cumulative values at reach level is shown in Fig. 7a, illustrating only the LW processes taking place in each reach, thus excluding the upstream drainage area. From this analysis, it is evident how both LW erosion and deposition featured a higher magnitude in the Gravegnola, where also more marked differences are present among the different reaches. In addition, the deposition does not only occur in the lower part of the catchments. Depositional reaches are
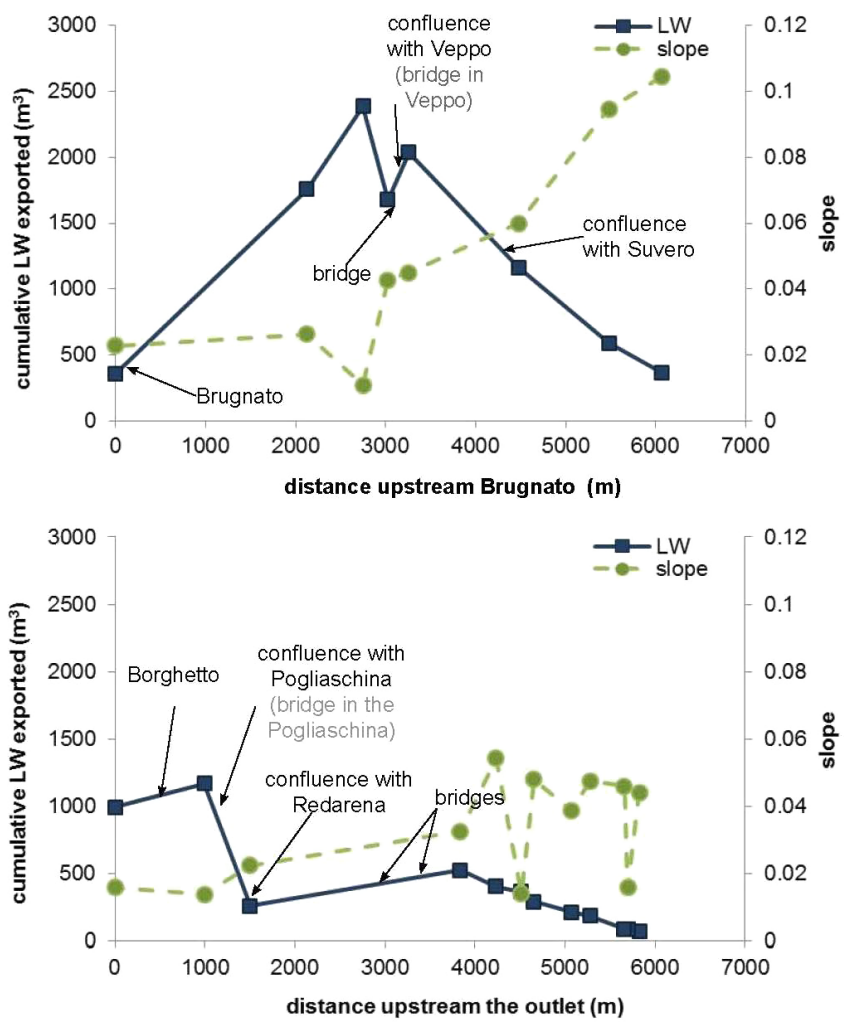

Figure 8. Cumulative LW exported and slope variability at reach scale along the longest flow paths in the Gravegnola (above) and Pogliaschina (below).

evidenced in the upper part of the Gravegnola main channel and downstream of the confluence between the Cassana and the Redarena creeks due to the presence of bridges and islands. Figure $7 \mathrm{~b}$ shows LW recruitment areas at reach scale in the Veppo Creek, including the locations of floodplains, landslides and a small tributary that supplied LW to the main channel. The location of a bridge that caused large LW deposition as well as of standing trees that trapped some wood elements are also shown. Figure 8 shows instead the longitudinal variation of $\mathrm{LW}$ exported at the reach scale in the Gravegnola and Pogliaschina basins, evaluated along the longest channel path in the two networks. The concurrent changes in channel slope and the presence of obstacles such as bridges are also reported in the graphs.

\subsection{Control factors and LW dynamics at the reach scale}

Some correlations between LW-related variables and controlling factors turn out to be statistically significant (Table 3), although they are rather weak and often show opposite signs in the two data sets (Pogliaschina and Gravegnola basins). For example, the widening ratio shows a positive correlation with drainage area in both catchments and negative with the reach channel slope, but only in the Pogliaschina this correlation is significant. 

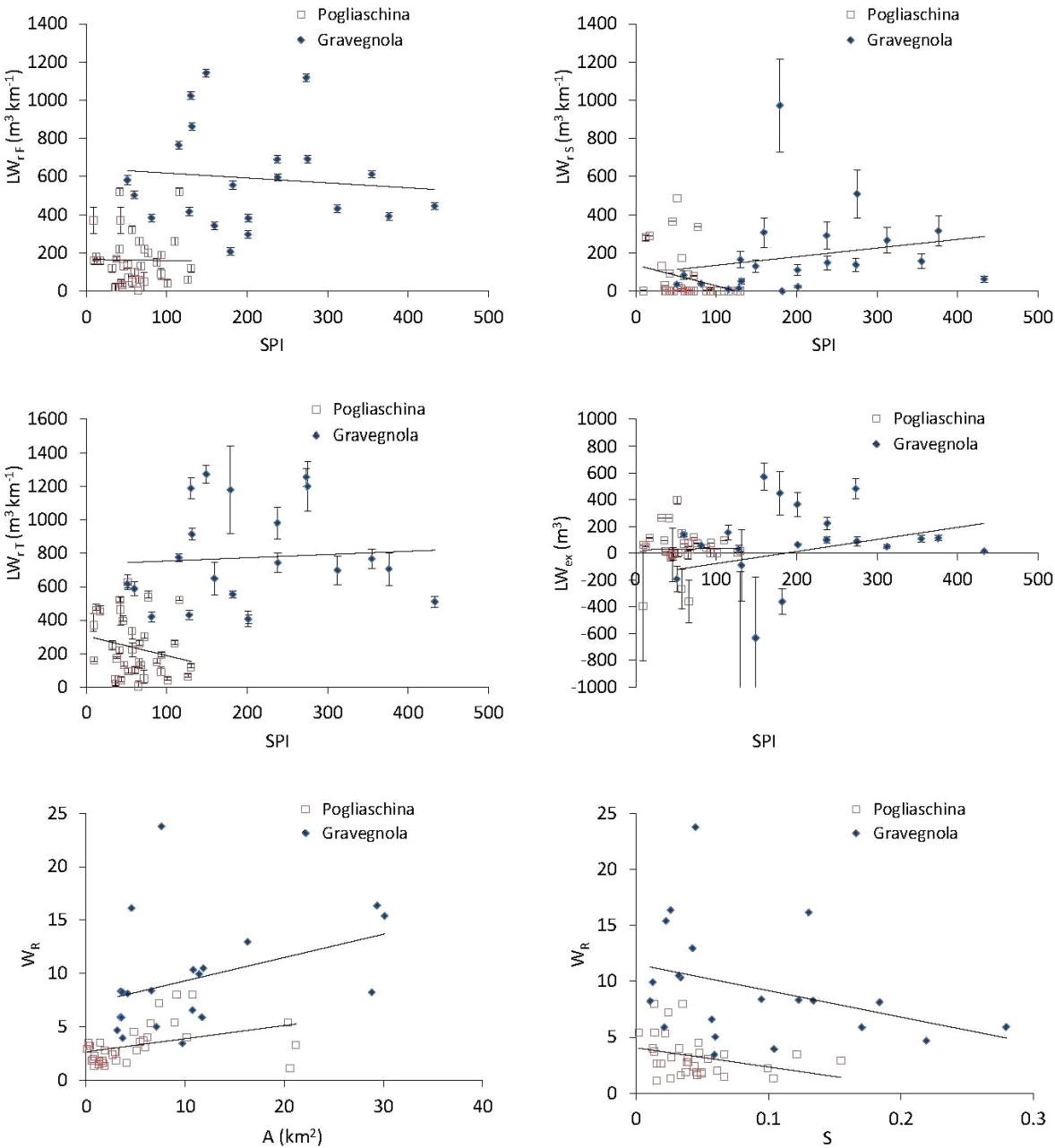

Figure 9. Relationships between selected control factors $(\mathrm{SPI}=$ Stream Power Index $)$ and $\mathrm{LW}$ variables $(\mathrm{LW} \mathrm{r} F=\mathrm{LW}$ recruitment rate in the fluvial corridor; $\mathrm{LW}_{\mathrm{r} S}=\mathrm{LW}$ recruitment rate in the hillslopes; $\mathrm{LW}_{\mathrm{r} T}=\mathrm{LW}$ recruitment rate in both, fluvial corridor and hillslopes; $\mathrm{LW}_{\mathrm{ex}}=\mathrm{LW}$ exported). The relationship between widening ratio $\left(W_{\mathrm{R}}\right)$ and drainage area $(A)$ and channel slope $(S)$ is shown too. The error bars express the uncertainty deriving from the range of assumptions for the estimate of LW volumes (see methods).

Table 3. Spearman correlation coefficients. In bold are correlations statistically significant $(p<0.05)$. For symbols see the notation list.

\begin{tabular}{lrrrrrrr|rrrrrrr}
\hline & \multicolumn{1}{c}{ Gravegnola } & \multicolumn{1}{c}{ Pogliaschina } \\
\cline { 2 - 14 } & $\mathrm{LW}_{\mathrm{r} F}$ & $\mathrm{LW}_{\mathrm{r} S}$ & $\mathrm{LW}_{\mathrm{r} T}$ & $\mathrm{LW}_{\mathrm{d}}$ & $\mathrm{LW}_{\mathrm{ex}}$ & $\mathrm{LW}_{\mathrm{ex} \mathrm{R}}$ & $W_{\mathrm{R}}$ & $\mathrm{LW}_{\mathrm{r} F}$ & $\mathrm{LW}_{\mathrm{r} S}$ & $\mathrm{LW}_{\mathrm{r} T}$ & $\mathrm{LW}_{\mathrm{d}}$ & $\mathrm{LW}_{\mathrm{ex}}$ & $\mathrm{LW}_{\mathrm{ex} \mathrm{R}}$ & $W_{\mathrm{R}}$ \\
\hline$S$ & -0.12 & $\mathbf{0 . 5 2}$ & 0.11 & -0.11 & $\mathbf{- 0 . 4 6}$ & 0.08 & -0.41 & $\mathbf{- 0 . 4 1}$ & 0.08 & -0.22 & 0.05 & $\mathbf{- 0 . 5 1}$ & -0.04 & $\mathbf{- 0 . 3 9}$ \\
$A$ & 0.22 & $\mathbf{- 0 . 5 0}$ & 0.01 & 0.22 & $\mathbf{0 . 5 8}$ & -0.07 & $\mathbf{0 . 5 0}$ & $\mathbf{0 . 5 0}$ & -0.29 & 0.19 & -0.04 & $\mathbf{0 . 5 6}$ & -0.12 & $\mathbf{0 . 4 9}$ \\
$\Omega$ & 0.35 & 0.38 & 0.41 & 0.25 & -0.23 & -0.09 & 0.07 & -0.16 & -0.07 & -0.18 & -0.24 & 0.01 & -0.26 & -0.10 \\
$\mathrm{SPI}$ & -0.04 & $\mathbf{0 . 4 8}$ & 0.13 & -0.05 & -0.42 & 0.08 & -0.33 & -0.05 & -0.26 & -0.20 & -0.14 & -0.06 & -0.28 & -0.05 \\
\hline
\end{tabular}

$S=$ Channel slope

$A\left(\mathrm{~km}^{2}\right)=$ Drainage area

$\Omega\left(\mathrm{W} \mathrm{m}^{-1}\right)=$ Stream power

SPI $(\mathrm{m})=$ Stream Power Index $\left(S \times A^{0.5}\right)$

$W_{\mathrm{R}}=$ Widening ratio $($ pre event width/post event width)

$\mathrm{LW}_{\mathrm{r} F}\left(\mathrm{~m}^{3} \mathrm{~km}^{-1}\right)=\mathrm{LW}$ recruitment rate in the fluvial corridor

$\mathrm{LW}_{\mathrm{r} S}\left(\mathrm{~m}^{3} \mathrm{~km}^{-1}\right)=\mathrm{LW}$ recruitment rate in the hillslopes

$\mathrm{LW}_{\mathrm{r} T}\left(\mathrm{~m}^{3} \mathrm{~km}^{-1}\right)=\mathrm{LW}$ recruitment rate in both, fluvial corridor and hillslopes

$\mathrm{LW}_{\mathrm{d}}\left(\mathrm{m}^{3} \mathrm{~km}^{-1}\right)=\mathrm{LW}$ deposition rate

$\mathrm{LW}_{\mathrm{ex}}\left(\mathrm{m}^{3}\right)=\mathrm{LW}$ exported ( $\mathrm{LW}$ input from upstream $+\mathrm{LW}$ recruited in the reach $-\mathrm{LW}$ deposited in the reach)

$\mathrm{LW}_{\mathrm{exR}}\left(\mathrm{m}^{3}\right)=\mathrm{LW}$ export ratio (LW Export/LW input from upstream $+\mathrm{LW}$ recruited in the reach) 

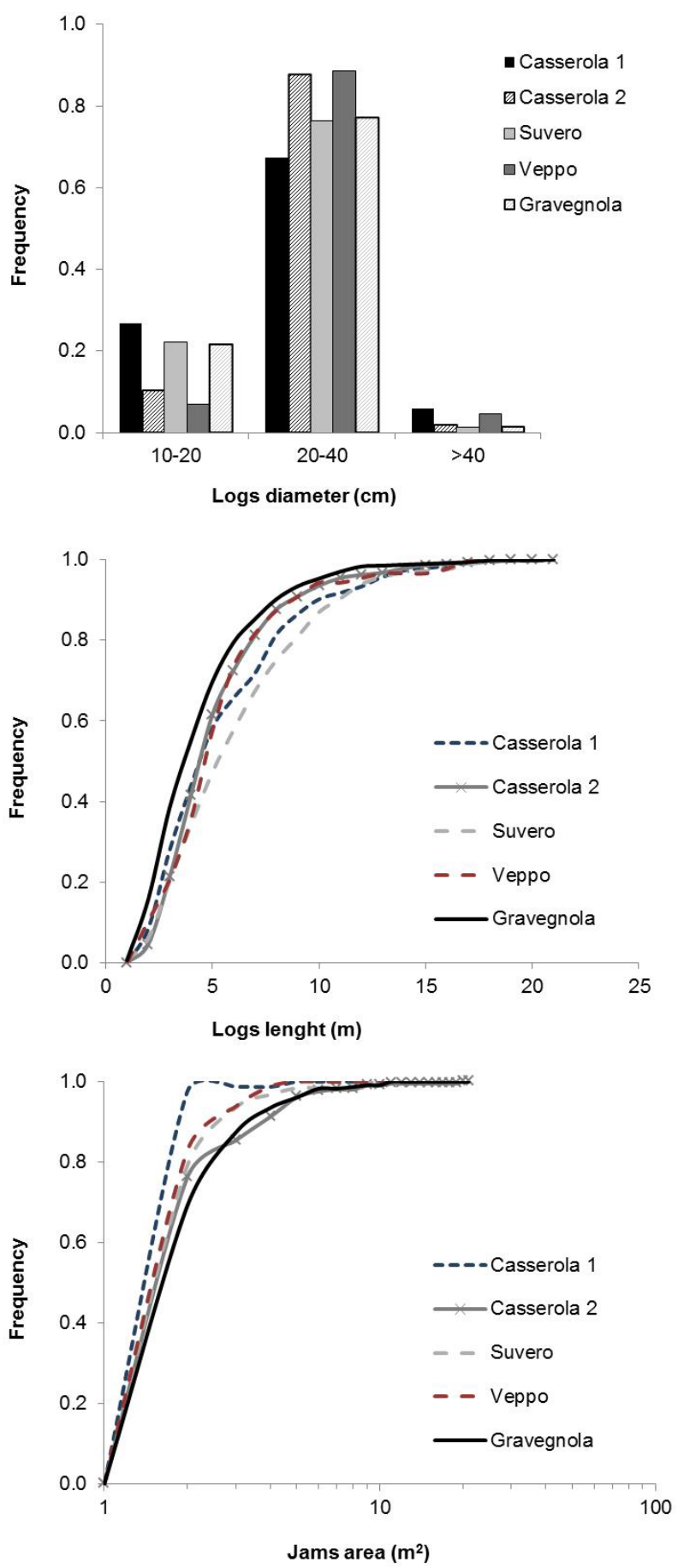

Figure 10. Frequency of log dimensions: the three categories of $\log$ diameter (above) the length (middle) and the jam area (below) in the different channels.

Within the Pogliaschina, fluvial LW erosion correlates significantly also with drainage area (positively) and longitudinal reach slope (negatively). On the other hand, LW recruited from the hillslope does not show any statistically significant correlation with any of the control factors for the
Pogliaschina data set, but it does so in the Gravegnola basin, where it is correlated negatively with drainage area and positively with longitudinal reach slope and stream power index. This could be due to the fact that some of the landslides were probably caused by bank erosion in this catchment.

Relatively surprising is the fact that LW deposition does not present statistically significant correlation with any of the control variables in both catchments. Instead, LW export from a reach is significantly and negatively correlated with the longitudinal reach slope, whereas it is positively correlated with drainage area in both catchments. Finally, the LW export ratio is not significantly correlated with any of the tested control variables.

Summarizing the correlation analysis results, LW dynamics are poorly correlated with any of the hydraulic variables. The graphs in Fig. 9 show that LW-related variables (as well as the widening ratio) in the Gravegnola channel network plot are generally much higher than in the Pogliaschina for comparable values of SPI, slope, and drainage area. The graphs illustrate the large variability inherent in the analysed data sets, which determines the low coefficients of correlation.

\subsection{Size of LW deposited in the Gravegnola basin}

As described in the methods section, the size of all LW jams and single elements could be measured within the GIS system for the Gravegnola basin only, thanks to the high quality of the orthophotos taken there after the event. A total of $1747 \operatorname{logs}$ and 654 jams were digitized, and a summary of their characteristics is reported in Table 4. Log length varies between $1 \mathrm{~m}$ and $18 \mathrm{~m}$, plus an outlier (a single tree) of $38 \mathrm{~m}$. Jam area features a high variability, ranging from 1 to $1700 \mathrm{~m}^{2}$.

Logs in the Gravegnola Creek are shorter than in the other channels, whereas there is no significant difference between the two reaches of the Casserola and the Veppo creeks. On the other hand, the Suvero Creek presents longer logs. These differences could be due to the fragmentation of LW pieces during the transport to the downstream reaches. Because the $\log$ diameter - different from log length - was assigned based on three classes (see methods), its distribution for the different channel is shown as histograms (Fig. 10). Diameter distributions are also non-normal, a median value is the same in all the Gravegnola channels.

The Casserola 1 is the channel in which jams are significantly smaller, then intermediate size jams are present in the Veppo, Suvero and Casserola 2 creeks, and the larger jams are found in the Suvero, Casserola 2 and Gravegnola channels. 
Table 4. LW characteristics (dimensions and spatial density) in the Gravegnola catchment. For symbols see the notation list.

\begin{tabular}{lrrrrr|rrrrr}
\hline Channel & $N_{\log }$ & $M_{\mathrm{e}} L_{\log }$ & $L_{\log 90}$ & $N_{\log L}$ & $N_{\log A}$ & $N_{\text {jam }}$ & $M_{\mathrm{e}} A_{\text {jam }}$ & $A_{\text {jam } 90}$ & $A_{\text {jam L }}$ & $A_{\text {jam A }}$ \\
\hline Casserola 1 & 376 & 4.34 & 9.9 & 11.2 & 0.44 & 77 & 7.4 & 19 & 29 & 1.1 \\
Casserola 2 & 371 & 4.53 & 8.6 & 25.5 & 0.24 & 205 & 19.3 & 140 & 863 & 8.3 \\
Suvero & 444 & 5.26 & 10.9 & 24.8 & 0.47 & 62 & 19 & 72 & 139 & 2.7 \\
Veppo & 88 & 4.52 & 8.6 & 4.8 & 0.14 & 81 & 14.7 & 63 & 127 & 3.6 \\
Gravegnola & 468 & 3.61 & 7.9 & 15.5 & 0.21 & 229 & 24.5 & 114 & 433 & 6.0 \\
\hline Total & 1747 & 4.37 & 9.6 & 15.2 & 0.28 & 654 & 17.3 & 104 & 275 & 5.1 \\
\hline
\end{tabular}

$N_{\log }=$ Number of logs

$M_{\mathrm{e}} L_{\log }(\mathrm{m})=$ Median of log length

$L_{\log 90}(\mathrm{~m})=90$ th percentile of the log length

$N_{\log L}(\operatorname{logs} \times 100 \mathrm{~m})=$ Number of $\operatorname{logs}$ per $100 \mathrm{~m}$ of streambed length

$N_{\log A}\left(\log\right.$ pieces $\left.\times 100 \mathrm{~m}^{2}\right)=$ Number of $\operatorname{logs}$ per $100 \mathrm{~m}^{2}$ of streambed area after flood

$N_{\mathrm{jam}}=$ Number of jams in the channel

$M_{\mathrm{e}} A_{\text {jam }}\left(\mathrm{m}^{2}\right)=$ Median of jam area

$A_{\text {jam } 90}\left(\mathrm{~m}^{2}\right)=90$ th percentile of the jam area

$A_{\text {jam } L}(\operatorname{logs} \times 100 \mathrm{~m})=$ Number of logs per $100 \mathrm{~m}$ of streambed length

$A_{\text {jam } A}\left(\log\right.$ pieces $\left.\times 100 \mathrm{~m}^{2}\right)=$ Number of $\operatorname{logs}$ per $100 \mathrm{~m}^{2}$ of streambed area after flood

\section{Discussion}

The magnitude of LW recruitment and deposition which occurred during the October 2011 flash flood in the study basins was characterized by a very high variability at different spatial scales, i.e. catchment, sub-catchment and reach scale. An interpretation of the observed evidence is provided below.

\subsection{LW recruitment and channel widening}

At the basin scale, most LW recruitment (about 70-80\%) originated from the fluvial corridors, with a much smaller contribution from the hillslopes, similar to what was observed during the 2005 flood events in Switzerland (Waldner et al., 2007). Therefore, channel widening was more important than hillslope movements in collecting wood from forested surfaces. The relevance of floodplain erosion was greater in the Gravegnola than in the Pogliaschina basin. Indeed, the analysed channels in the former catchment widened - in both absolute and relative terms - more than in the latter (median of widening ratio approximately 8 vs. 3 , respectively). The range in the widening ratio is similar to the one observed after the severe 2005 floods in the Austrian Alps (Krapesch et al., 2011); however, contrary to our case, no significant differences among the studied catchments were evidenced.

The stream power does differ considerably between the two catchments, mostly for the steeper slopes characterizing the Gravegnola channel network. Therefore, the results at the basin scale seem to indicate that channel widening could be related to the total power of the flow. However, the results at the reach scale (Table 3) do not support the hypothesis that channel widening, and thus LW recruitment from the floodplain, correlates with stream power.
Variables related to channel width, e.g., unit stream power or unit stream power index (Rigon et al., 2012), were not taken into account for the analysis. In fact, the width of the studied channels greatly varied during the event, making the selection of the appropriate (pre- vs. post-event) width highly disputable. Indeed, pre-event widths ranged in most reaches between 3 and $5 \mathrm{~m}$, but accurate estimations were hindered by the dense forest canopy overhanging on channels. Therefore, if the pre-event width was used to calculate the unit stream power, correlations with LW variables would not differ from those obtained by using the stream power, and actually higher uncertainty would be added. On the other hand, as channel widening and LW recruitment from the fluvial corridor are directly related to the eroded areas that mostly determine the post-event width, spurious correlations between these variables and unit stream power would enter the analysis if post-event width was adopted. Moreover, the pre-event width is of little relevance for our relatively small range of channel size. Therefore the role of unit stream power could be addressed here, unlike in Krapesch et al. (2011) who analysed a data set comprising of both small and relatively large channels (based on the before the event width).

The drainage area only resulted to be significantly correlated with the widening ratio for the two basins separately (Table 3). The channel slope seems also relevant, but its correlation coefficients are slightly smaller. The negative correlation between widening ratio and channel slope can be ascribed to the higher confinement of upstream channels. In these reaches, which are more confined and steeper, vertical variations (incision) are more likely to occur rather than horizontal variations (widening). On the contrary, horizontal variations are more likely to occur in the low gradient and unconfined downstream reaches. Overall, drainage area and channel slope (which are strongly and negatively correlated, $R^{2}=0.78$ and 0.46 in the power function of the Gravegnola 
and Pogliaschina, respectively) perform better than stream power or SPI in explaining the variability of widening ratio and LW recruitment (both from the floodplain and hillslopes). This indicates that the lower, milder reaches in both catchments underwent larger widening, but the physical process/reason for its occurrence remain unclear, as well as the fact that Gravegnola reaches featured much larger widening and thus larger LW floodplain recruitment than those in the Pogliaschina, despite the partial overlap in drainage area and channel slope (Fig. 9).

A factor potentially responsible for these differences could be the degree of channel confinement, i.e. the ratio between valley floor width and channel width. This is an obvious boundary condition for rivers with a narrow fluvial corridor, but it could not be assessed with accuracy in the study basins due to the inadequate geological map scale and DEM resolution. However, we believe that sediment supply and bedload deposition during the event played a major role in determining channel widening and thus floodplain recruitment. Indeed, the total surface affected by landslides coupled to the channel network was 10.5 ha in the Gravegnola basin but only 1.39 ha in the Pogliaschina. The higher amount of sediment supplied to the channels of the Gravegnola catchment likely triggered widespread avulsions and increased lateral mobility processes within this basin. As these processes are more intense where strong deposition tends to occur (Bryant et al., 1995), widening increases moving downstream in the fluvial network, where lower channel slopes and larger drainage areas are present.

The higher landslide coupling with channels (in terms of LW) during the event in the Gravegnola basin compared to the Pogliaschina likely depends on the different geological characteristics of the catchments. In the Gravegnola, landslides - mainly translational slides - were relatively larger and more effectively connected (in terms of LW, but possibly also in terms of sediment) to the main channel than in the Pogliaschina (Fig. 11). Also, landslide sediment volumes were probably greater in the Gravegnola due to their larger thickness, which is related to the geological characteristics of the catchment. In fact, $21.6 \%$ of the Gravegnola catchment was mapped - before the 2011 event - as landslide deposits, and almost half $(47 \%)$ of the hillslope areas which contributed LW to the channels during the event was mapped as paleo-landslides. In contrast, in the Pogliaschina catchment only $2.8 \%$ was mapped as landslide deposit, and nearly half of the basin area is underlain by the Macigno fm., which is quite stable and featured quite a few landslides in comparison with the Monte Gottero formation (Mondini et al., 2014).

\subsection{LW deposition}

LW deposition appears to be even more difficult to explain than recruitment, as correlation analysis did not evidence any statistically significant relationship with the tested control-
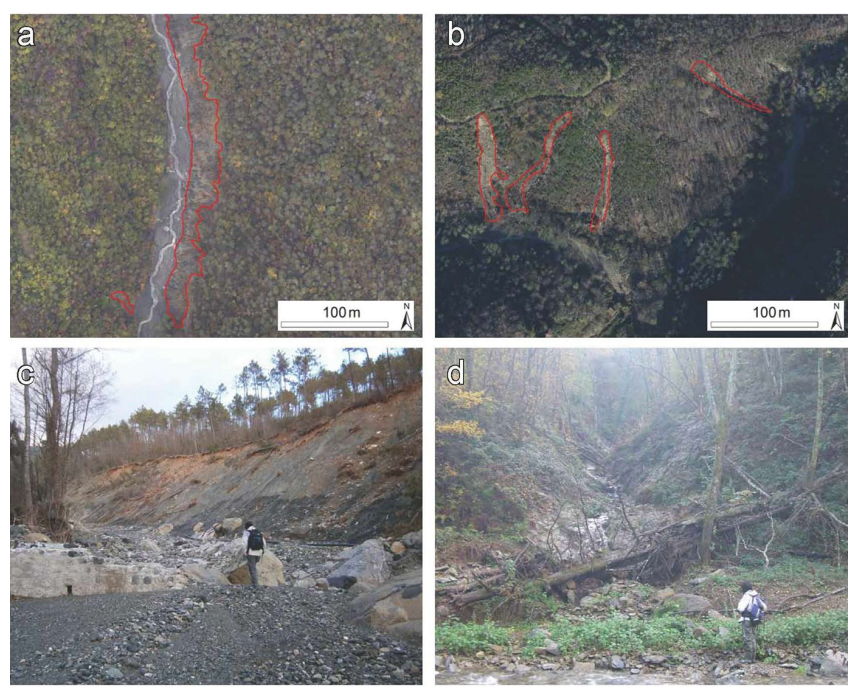

Figure 11. Example of lateral inputs (marked in red in the orthophotos, $\mathbf{a}, \mathbf{b})$ of sediment to the channel. In the Gravegnola $(\mathbf{a}, \mathbf{c})$ the lateral input consists in large landslides connected to the channel, while in the Pogliaschina (b, d) the connectivity of sediments from the slopes is lower because it mostly occurs through earth flows, which are partly buffered by valley floors, and channelized erosion in ephemeral streams that are sometimes blocked by LW pieces.

ling variables. Nonetheless, deposition seems to have been more pronounced in the wider, milder slope reaches, typically located in the lower river sections (Fig. 8). This contrasts to what was observed in mountain catchments in the Italian Alps where LW storage was analysed long after extreme events occurred (Comiti et al., 2006; Rigon et al., 2012), but matches observations carried out after the 2005 flood events in Switzerland (Waldner et al., 2007). In our study basins, LW deposition was severely affected by the presence of newly-formed islands (from floodplain dissection) or even of single standing trees, which - similar to bridges - were key in promoting wood trapping. The lower values of reach-scale LW export (Fig. 8) actually characterize reaches where bridges were clogged or where standing vegetation (islands) trapped large amount of wood (as in the Redarena and Veppo creeks) (Fig. 7b). Indeed, these elements, in particular bridges, should be considered as the first order factors controlling wood transport during flood events.

The volumes of LW deposited in the channels are slightly higher than LW storage reported for European mountains rivers, but assessed a long time after extreme flood events occurred (Rigon et al., 2012). Also, they are similar to LW storage in different channels of Chile (Iroumé et al., 2014) and headwater streams in the Colorado Rocky Mountains (Wohl and Goode, 2008), but definitely smaller than in rivers flowing in regions like the Pacific Northwest (Gurnell, 2003; Wohl, 2014).

Furthermore, LW sizes measured in detail in the Gravegnola basin are small compared to the latter, well-investigated 
geographical area, where old-growth conifer forests supply channels with very large wood elements. On the other hand, deposited logs in the Gravegnola are on average longer - and larger - than those measured in mountain catchments of the Italian Alps (Comiti et al., 2006; Rigon et al., 2012), but are quite similar to LW surveyed in Switzerland after the 2005 floods (Waldner et al., 2007). In fact, nearly all LW measured in the Gravegnola after the flood derived from freshly recruited trees - as estimated from wood characteristics, see MacVicar et al. (2009) - which were not subject to breaking up processes over the years, as also reported for the Swiss study case (Waldner et al., 2007).

\section{Conclusions}

This study highlights the complexity of wood dynamics in mountainous catchments during flash floods, and thus the difficulties in predicting LW budgets and LW-related hazards during floods. Therefore, the managing practices tend to be conservative about the risk reduction at the expense of quality of the aquatic habitat. The large uncertainties in forecasting a reliable flood event LW budget lie in the prediction of both LW recruitment and deposition. Indeed, rivers featuring similar flood severity responded quite differently in terms of channel widening and thus of wood recruitment from the floodplains, which was the dominant process for LW recruitment in partly-confined channels. More post-event investigations are thus needed to understand the factors responsible for channel widening during extreme events. A specific investigation about the widening processes occurred during the 25 October 2011 flood event in several channels within the Magra river basin - including the Gravegnola and Pogliaschina - is presented in Surian et al. (2015). Differences in degree of channel widening between this study and the paper by Surian et al. (2015) are due to a different selection of the channel reaches, as well as to their different segmentation (here focusing on LW dynamics rather than on uniform reach lengths).

Wood recruited by hillslope processes was quantitatively relevant as well, but also in this case its prediction would encounter the large uncertainties inherent in the prediction of hillslope instabilities, elevated by the necessity to assess their connectivity with the channel network. To this aim, the GIS-based model developed by Lucía et al. (2015) - which extends to LW dynamics the Cavalli et al. (2013) approach for sediment connectivity - is a first attempt to address such an issue considering also LW propagation along the channel network.

Finally, LW deposition - and thus LW export - at the reach scale was observed to be a very complex process too, being poorly related to any hydro-morphological variable and highly influenced by the presence of standing trees and artificial structures such as bridges.
From an applicative perspective, maintenance of riparian vegetation present in the river corridors of study basins with periodic selective cuts would have surely reduced the recruited volumes. However, large LW quantities would have been still supplied by landslides, these being probably enough to cause several bridge clogging and thus determine an increased flood hazard. Therefore, we believe that a renewed approach to bridge design and/or the installation of ad hoc retention structures (Comiti et al., 2012) are the only solutions to reduce substantially the damages caused by wood transport during extreme floods. This points out the general suitability of these studies that document the patterns and amounts of LW erosion and deposition, which may be useful for the managers of mountain river basins who very often have to cope with wood transport processes during extreme events, a potential hazard still poorly considered in many hazard plans worldwide.

Acknowledgements. Funding for this study comes from the project TRUMPS (Towards a reliable inundation mapping in South Tyrol) granted by the Autonomous Province of Bozen-Bolzano, and from a grant of the Autorità di Bacino Interregionale del Fiume Magra (Law 183/89 funds). The "Servizio di Protezione Civile della Provincia della Spezia", and the "Corpo Forestale dello Stato - Comando Provinciale della Spezia" are warmly thanked for providing extremely valuable data. The authors wish to thank the colleagues Stefano Crema and Alessia Viero for their collaboration in field surveys and landslide mapping. Andrés Iroumé and two anonymous reviewers helped to improve the quality of this manuscript with their valuable comments and suggestions.

Edited by: L. Ferrari

Reviewed by: two anonymous referees

\section{References}

Andreoli, A., Comiti, F., and Lenzi, M. A.: Characteristics, distribution and geomorphic role of large woody debris in a mountain stream of the Chilean Andes, Earth Surf. Proc. Land., 32, 16751692, 2007.

Beckman, N. D. and Wohl, E.: Carbon storage in mountainous headwater streams: The role of old-growth forest and logjams, Water Resour. Res., 50, 2376-2393, 2014.

Benda, L., Miller, D., Sias, J., Martin, D., Bilby, R. E., Veldhuisen, C., and Dunne, T.: Wood recruitment processes and wood budgeting, in: The Ecology and Management of Wood in World Rivers, edited by: Gregory, S. V., Boyer, K. L., and Gurnell, A. M., American Fisheries Society Symposium, Bethesda, Maryland, 23-27 October 2000, 299-313, 2003.

Borga, M., Boscolo, P., Zanon, F., and Sangati, M.: Hydrometeorological analysis of the 29 August 2003 flash flood in the Eastern Italian Alps, J. Hydrometeorol., 8, 1049-1067, 2007.

Borga, M., Stoffel, M., Marchi, L., Marra, F., and Jakob, M.: Hydrogeomorphic response to extreme rainfall in headwater systems: flash floods and debris flows, J. Hydrol., 518, 194-205, 2014. 
Bryant, M., Falk, P., and Paola, C.: Experimental study of avulsion frequency and rate of deposition, Geology, 23, 365-368, 1995.

Castiglioni, G. B.: Le calamità naturali nelle Alpi., XXI Congresso Geografico Italiano, Istituto di Geografia, Università di Padova, 335 pp., 1974 (in Italian).

Cavalli, M., Trevisani, S., Comiti, F., and Marchi, L.,: Geomorphometric assessment of spatial sediment connectivity in small Alpine catchments, Geomorphology, 188, 31-41, 2013.

Comiti, F., Andreoli, A., Lenzi, M. A., and Mao, L.: Spatial density and characteristics of woody debris in five mountain rivers of the Dolomites (Italian Alps), Geomorphology, 78, 44-63, 2006.

Comiti, F., Mao, L., Preciso, E., Picco, L., Marchi, L., and Borga, M.: Large wood and flash floods: evidences from the 2007 event in the the Davča basin (Slovenia). In: Monitoring, simulation, prevention and remediation of dense and debris flow, 60, WIT press, UK, 2008.

Comiti, F., D’Agostino, V., Moser, M., Lenzi, M. A., Bettella, F., Dell'Agnese, A., Rigon, E., Gius, S., and Mazzorana, B.: Preventing wood-related hazards in mountain basins: from wood load estimation to designing retention structures, in: Koboltschnig, G., Hübl, J., and Braun, J., $12^{\circ}$ Congress Interpraevent, 23-27 April 2012, Grenoble, 2, 651-662, 2012.

Cordova, J. M., Rosi-Marshall, E. J., Yamamuro, A. M., and Lamberti, G. A.: Quantity, controls and functions of large woody debris in Midwestern USA streams, River Res. Appl., 23, 21-33, 2007.

Davies, T. R. and Scott, B. J.: Landslide dam-break flood hazard from the Callery Gorge, South Westland, New Zealand, J. Hydrol. (N.Z.), 36, 1-13, 1997.

Diehl, T. H.: Potential Drift Accumulation at Bridges, U.S. Department of Transportation, Federal Highway Administration Research and Development, Turner-Fairbank Highway Research Center, Virginia, 1997.

Doocy, S., Daniels, A., Murray, S., and Kirsch, T. D.: The human impact of floods: a historical review 5 of events 1980-2009 and systematic literature review, PLoS Curr., 16, 12 pp., 2013.

Faustini, J. M. and Jones, J. A.: Influence of large woody debris on channel morphology and dynamics in steep, boulder-rich mountain streams, western Cascades, Oregon, Geomorphology, 51, 187-205, 2003.

Fischer, M.: Driftwood During the Flooding in Klosters in 2005 (in German), HSW Wädenswil, Switzerland, 2006.

Gaume, E. and Borga, M.: Post-flood field investigations in upland catchments after major flash floods: proposal of a methodology and illustrations, J. Flood Risk Manag., 1, 175-189, 2008.

Gregory, S. V., Boyer, K. L., and Gurnell, A. M. (Eds.): The Ecology and Management of Wood in World Rivers, Bethesda, Maryland, 2003.

Gschnitzer, T., Gems, B., Mazzorana, B., Comiti, F., and Aufleger, M.: On the evaluation and modelling of driftwood clogging processes in flood related hazards estimation, in: Engineering Geology for Society and Territory-River Basins. Reservoir Sedimentation and Water Resources, edited by: Lollino, G., Arattano, M., Rinaldi, M., Giustolisi, O., Marechal, J.-C., and Grant, G. E., Springer, 139-142, 2015.

Gurnell, A.: Plants as river system engineers, Earth Surf. Proc. Land., 39, 4-25, 2014.

Gurnell, A. M.: Wood Storage and Mobility, in: The Ecology and Management of Wood in World Rivers, edited by: Gregory, S.
V., Boyer, K. L., and Gurnell, A. M., American Fisheries Society Symposium, Bethesda, Maryland, 23-27 October 2000, 2003.

Hassan, M. A., Hogan, D. L., Bird, S. A., May, C. L., Gomi, T., and Campbell, D.: Spatial and temporal dynamics of wood in headwater streams of the Pacific Northwest, J. Am. Water Resour. Assoc., 41, 899-919, 2005.

IAHS-UNESCO-WMO (Ed.): Flash Floods, Proceedings of the Paris Symposium, September 1974, 1974.

Iroumé, A., Mao, L., Ulloa, H., Ruz, C., and Andreoli, A.: Large Wood Volume and Longitudinal Distribution in Channel Segments Draining Catchments with Different Land Use, Chile, Open J. Mod. Hydrol., 4, 57-66, 2014.

Iroumé, A., Mao, L., Andreoli, A., Ulloa, H., and Ardiles, M. P.: Large wood mobility processes in low-order Chilean river channels, Geomorphology, 228, 681-693, 2015.

Jonkman, S. N.: Global Perspectives on Loss of Human Life Caused by Floods, Nat. Hazards, 34, 151-175, 2005.

Kaczka, R.: Dynamics of large woody debris and wood dams in mountain Kamienica Stream, Polish Carpathians, in: TRACE - Tree Rings in Archaeology, Climatology and Ecology, vol. 7. Proceedings of the DENDROSYMPOSIUM 2008, 27302008 April, edited by: Kaczka, R., Malik, I., Owczarek, P., Gärtner, H., Helle, G., and Heinrich, I., Association for Tree Ring Research, Potsdam, Germany, 171-175, 2009.

Krapesch, G., Hauer, C., and Habersack, H.: Scale orientated analysis of river width changes due to extreme flood hazards, Nat. Hazards Earth Syst. Sci., 11, 2137-2147, doi:10.5194/nhess-112137-2011, 2011.

Lancaster, S. T. and Grant, G. E.: Debris dams and the relief of headwater streams, Geomorphology, 82, 84-97, 2006.

Lucía, A., Antonello, A., Campana, D., Cavalli, M., Crema, S., Franceschi, S., Marchese, E., Niedrist, M., Schneiderbauer, S., and Comiti, F.: Monitoring and modeling large wood transport in a mountain basin of North-eastern Italy, in: Engineering Geology for Society and Territory-River Basins. Reservoir Sedimentation and Water Resources, edited by: Lollino, G., Arattano, M., Rinaldi, M., Giustolisi, O., Marechal, J.-C., and Grant, G. E., Springer, 159-162, 2015.

MacVicar, B. J., Piégay, H., Henderson, A., Comiti, F., Oberlin, C., and Pecorari, E.: Quantifying the temporal dynamics of wood in large rivers: field trials of wood surveying, dating, tracking, and monitoring techniques, Earth Surf. Proc. Land., 34, 2031-2046, 2009.

Mao, L., Burnsc, S., Comiti, F., Andreoli, A., Urciuolo, A., GaviñoNovillo, M., Iturraspe, R., and Lenzi, M. A.: Acumulaciones de detritos leñosos en un cauce de montaña de Tierra del Fuego: análisis de la movilidad y de los efectos hidromorfológicos, LW jams in a mountain stream of Tierra del Fuego: piece movement and hydro-morphological effects analysis, Bosque, 29, 197-211, 2008 (in Spanish).

Marchi, L. and Dalla Fontana, G.: GIS morphometric indicators for the analysis of sediment dynamics in mountain basins, Environ. Geol., 48, 218-228, 2005.

Marchi, L., Borga, M., Preciso, E., Sangati, M., Gaume, E., Bain, V., Delrieu, G., Bonnifait, L., and Pogačnik, N.: Comprehensive post-event survey of a flash flood in Western Slovenia: observation strategy and lessons learned, Hydrol. Process., 23, 37613770, 2009. 
Mazzorana, B., Zischg, A., Largiader, A., and Hübl, J.: Hazard index maps for woody material recruitment and transport in alpine catchments, Nat. Hazards Earth Syst. Sci., 9, 197-209, doi:10.5194/nhess-9-197-2009, 2009.

Mazzorana, B., Hübl, J., Zischg, A., and Largiader, A.: Modelling woody material transport and deposition in alpine rivers, Nat. Hazards, 56, 425-449, 2011.

Mondini, A. C., Viero, A., Cavalli, M., Marchi, L., Herrera, G., and Guzzetti, F.: Comparison of event landslide inventories: the Pogliaschina catchment test case, Italy, Nat. Hazards Earth Syst. Sci., 14, 1749-1759, doi:10.5194/nhess-14-1749-2014, 2014.

Nardi, L. and Rinaldi, M.: Spatio-temporal patterns of channel changes in response to a major flood event: the case of the Magra River (central - northern Italy), Earth Surf. Proc. Land., 40, 326-339, 2015.

Rickenmann, D.: Schwemmholz und hochwasser Wasser Energie, Luft, 89, 115-119, 1997 (in German).

Rigon, E., Comiti, F., and Lenzi, M. A.: Large wood storage in streams of the Eastern Italian Alps and the relevance of hillslope processes, Water Resour. Res., 48, W01518, doi:10.1029/2010wr009854, 2012.

Rinaldi, M., Amponsah, W., Benvenuti M., Borga, M., Comiti, F., Lucía, A., Marchi, L., Nardi, L., Righini, M., and Surian, N.: An integrated approach for investigating geomorphic response to an extreme flood event: the case of the Magra River, Italy, Earth Surf. Proc. Land., in review, 2015.

Ruiz-Villanueva, V., Díez-Herrero, A., Bodoque, J. M., Ballesteros Cánovas, J. A., and Stoffel, M.: Characterisation of flash floods in small ungauged mountain basins of Central Spain using an integrated approach, Catena, 110, 32-43, 2013a.

Ruiz-Villanueva, V., Bladé Castellet, E., Díez-Herrero, A., Bodoque, J. M., and Sánchez-Juny, M.: Two-dimensional modelling of large wood transport during flash floods, Earth Surf. Proc. Land., 39, 438-449, 2013 b.
Ruiz-Villanueva, V., Bladé, E., Sánchez-Juny, M., Marti-Cardona, B., Díez-Herrero, A., and Bodoque, J. M.: Two dimensional numerical modeling of wood transport, J Hydroinform, 2014a.

Ruiz-Villanueva, V., Díez-Herrero, A., Ballesteros, J. A., and Bodoque, J. M.: Potential large woody debris recruitment due to landslides, bank erosion and floods in mountain basins: A quantitative estimation approach, River Res. Appl., 30, 81-97, 2014b.

Schmocker, L. and Hager, W.: Probability of Drift Blockage at Bridge Decks, J. Hydraul. Eng.-ASCE, 137, 470-479, 2011.

Surian, N., Righini, M., Lucìa, A., Nardi, L., Amponsah, W., Benvenuti, M., Borga, M., Cavalli, M., Comiti, F., Marchi, L., Rinaldi, M., and Viero, A.: Channel response to extreme floods: insights on controlling factors from six mountain rivers in northern Apennines, Italy, Geomorphology, in review, 2015.

Swanson, F. J. and Lienkaemper, G. W.: Physical consequences of large organic debris in Pacific Northwest streams, USDA For. Serv. Gen. Tech. Rep. PNW-69, 12 pp., 1978.

Thévenet, A., Citterio, A., and Piégay, H.: A new methodology for the assessment of large woody debris accumulations on highly modified rivers (example of two French piedmont rivers), Regul River, 14, 467-483, 1998.

Waldner, P., Rickli, C., D., K., Usbeck, T., Schmocker, L., and Sutter, F. (Eds.): Schwemmholz. Ereignisanalyse Hochwasser 2005 - Teil 1: Prozesse, Schäden und erste Einordnung (in German), Umwelt-Wissen, 2007 (in German).

Wohl, E.: Redistribution of forest carbon caused by patch blowdowns in subalpine forests of the Southern Rocky Mountains, USA, Global Biogeochem. Cy., 27, 1205-1213, 2013.

Wohl, E.: Time and the rivers flowing: Fluvial geomorphology since 1960, Geomorphology, 216, 263-282, 2014.

Wohl, E. and Goode, J. R.: Wood dynamics in headwater streams of the Colorado Rocky Mountains, Water Resour. Res., 44, W09429, doi:10.1029/2007wr006522, 2008. 